\title{
A STUDY OF THE EFFECT OF THE EVAPORATIVE EROSION ON THERMOELECTRIC ELEMENTS ON THE PERFORMANCE OF THERMOELECTRIC GENERATORS
}

RAGON D. KINNEY,

Space Power Advanced Development Division

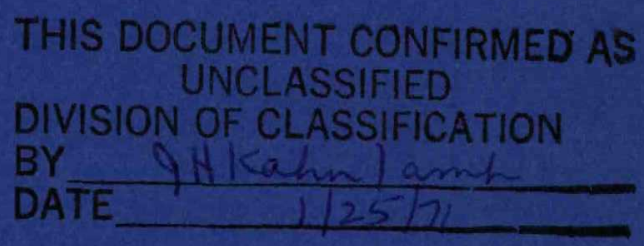




\section{DISCLAIMER}

This report was prepared as an account of work sponsored by an agency of the United States Government. Neither the United States Government nor any agency Thereof, nor any of their employees, makes any warranty, express or implied, or assumes any legal liability or responsibility for the accuracy, completeness, or usefulness of any information, apparatus, product, or process disclosed, or represents that its use would not infringe privately owned rights. Reference herein to any specific commercial product, process, or service by trade name, trademark, manufacturer, or otherwise does not necessarily constitute or imply its endorsement, recommendation, or favoring by the United States Government or any agency thereof. The views and opinions of authors expressed herein do not necessarily state or reflect those of the United States Government or any agency thereof. 


\section{DISCLAIMER}

Portions of this document may be illegible in electronic image products. Images are produced from the best available original document. 
Issued by Sandia Corporation,

a prime contractor to the United States Atomic Energy Commission

\section{NOTICE}

This report was prepared as an account of work sponsored by the United States Government. Neither the United States nor the United States Atomic Energy Commission, nor any of their employees, nor any of their contractors, subcontractors, or their employees, makes any warranty, express or implied, or assumes any legal liability or responsibility for the accuracy, completeness or usefulness of any information, apparatus, product or process disclosed, or represents that its use would not infringe privately-owned rights.

Available from the Clearinghouse

U. S. Department of Commerce,

Springfield, Virginia 22151

Price: Paper Copy $\$ 3.00$

Microfiche $\$ 0.65$ 


\author{
SC-RR-70-804
A STUDY OF THE EFFECT OF THE EVAPORATIVE EROSION ON THERMOELECTRIC ELEMENTS ON THE PERFORMANCE OF THERMOELECTRIC GENERA TORS

Ragon D. Kinney, 9522

Space Power Advanced Development Division

Sandia Laboratories

Albuquerque, New Mexico

87115

LEGAL NOTICE

This report was prepared as an account of work This report was prited States Government. Neither the United States Atomic Energy the Unted States nor the ef Commission, nor any of thactors, or their employees, their contractors, subcontractors, or the or assumes any makes any warranty, express or implied, or assumes any legal hability or responsibility for the accuracy, completeness or usefulness of any information, apparatus,

product or process disclosed, or represents

November 1970

\begin{abstract}
A model is presented and an analysis made of the material losses from thermoelectric elements in some thermoelectric generators and the effect of such loss on generator performance.
\end{abstract}

Key Words: PbTe, vapor transport 


\section{ACKNOWLEDGMENT}

The author wishes to acknowledge the assistance of Ivan Waddoups during this study; specifically, his effort in the use of the computer codes. 


\section{TABLE OF CONTENTS}

Page

Introduction

5

Model Description

5

Model Solution

Couple Behavioral Analysis

Model Limitations

Conclusions

REFERENCES 
BLANK 


\title{
A STUDY OF THE EFFECT OF THE EVAPORA TIVE EROSION ON THERMOELECTRIC ELEMENTS \\ ON THE PERFORMANCE OF THERMOELECTRIC GENERA TORS
}

\author{
Introduction
}

A mode of performance degradation in some thermoelectric generators is the erosion of material from the thermoelectric elements that comprise the generator. In pressurized generators using an inert gas to retard sublimation of the thermoelectric material, this erosion results from diffusive mass transport of vapor from the elements due to naturally occurring concentration gradients in the surrounding cover gas. The erosion occurs primarily at the hot end of the elements and diminishes the area of contact between the element and its electrical connection. This report presents an analysis of the effect erosion has on generator performance.

\section{Model Description}

Figure 1 depicts a longitudinal section of the configuration chosen for analysis, i. e., one element of a thermoelectric couple, typically a $\mathrm{PbTe}$ couple, surrounded by thermal insulation. Referring to this figure, the annular region between the cylindrical $\mathrm{PbTe}$ thermoelectric element and the surrounding thermal insulation is gas filled, and as a result of the element residing in the temperature gradient, $\left(\mathrm{T}_{\mathrm{h}}-\mathrm{T}_{\mathrm{c}}\right) / \ell$, concentration gradients of $\mathrm{PbTe}$ vapor exists in the annular region. These gradients promote the diffusion of material through the cover gas away from the hot end of the element, $z=0$. Steady state equilibrium is supported by material subliming from the element to replace that which diffuses away. Hence, the element erodes.

The configuration of Figure 1 represents well only those generator designs, such as the SNAP-19, which use a molded insulation around the thermoelectric element and have a relatively uniform gas filled annular region. However, the 


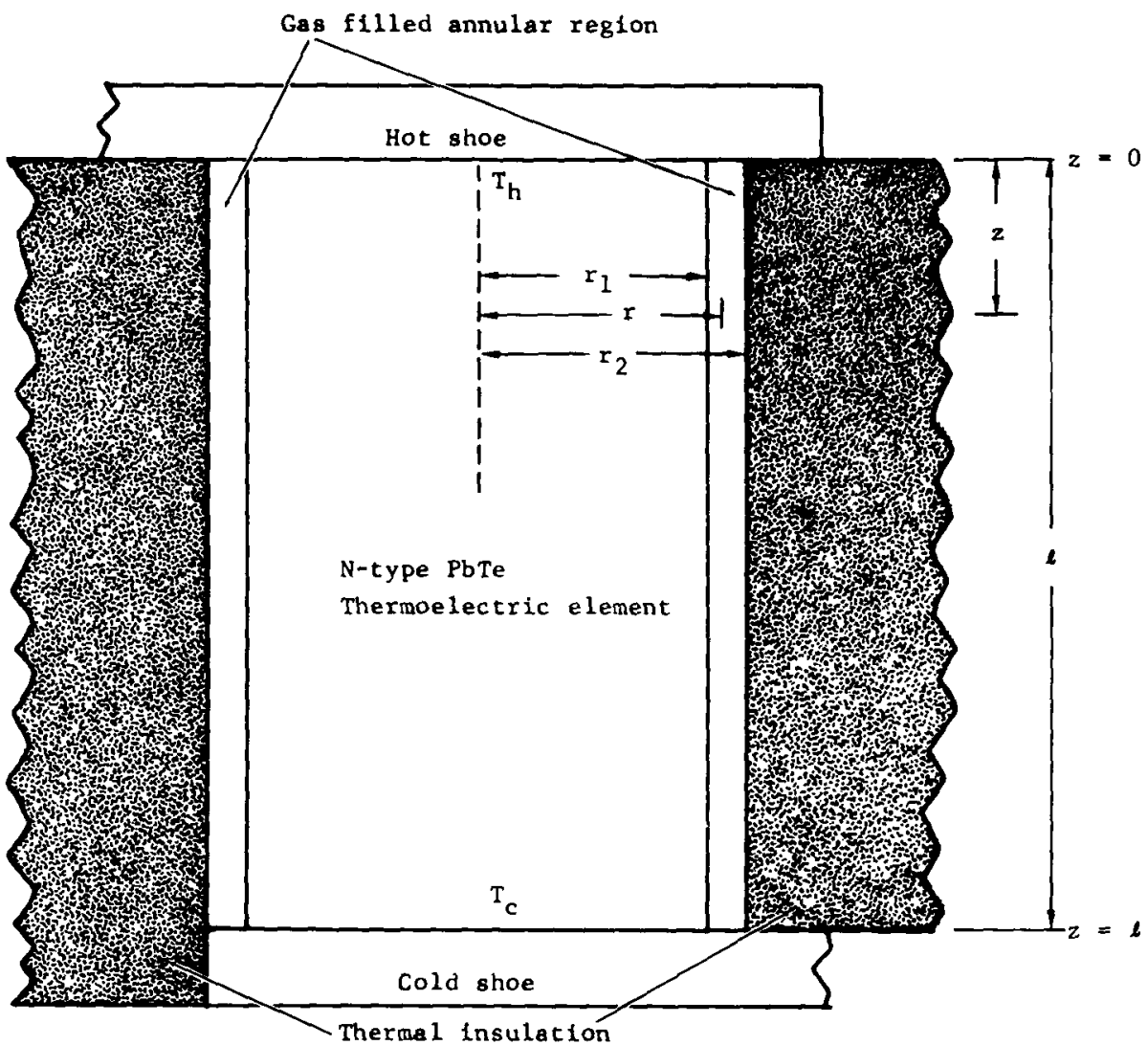

Figure 1. Configuration of thermoelectric element and thermal insulation used for analysis 
general trends revealed by the analysis can apply to more irregular geometries such as might occur on the SNAP-27 where the insulation has been powdered and lightly tamped around the thermoelectric elements, but where diffusion through the cover gas remains the dominant mode of mass transport.

Determining the deviation in total generator performance due to element erosion is accomplished by first developing an expression for predicting the contour of the thermoelectric element after time, $t$, and secondly by using this information in thermoelectric generator computer design codes to assess the performance of couples with eroded elements relative to their performance with whole elements.

An expression for the profile history of the thermoelectric element depicted in Figure 1 is developed by considering the time rate of change in the radius of the element due to erosion. This is given as

$$
\mathrm{dr} / \mathrm{dt}=-\mathrm{j}_{\mathrm{r}_{1}} / \rho
$$

where

$$
\begin{aligned}
r & =\text { radius of the thermoelectric element } \\
j_{r_{1}} & \text { steady state radial component of mass flux at the surface of } \\
& \text { the element, i. e., mass flux evaluated at } r=r_{1} . \\
\rho & =\text { density of thermoelectric material }
\end{aligned}
$$

Assuming the mass transport due to temperature gradients and bulk motion of the cover gas is negligible, and the total system pressure is spatially constant, the general form of the radial component of mass flux, $j_{r}$, can be expressed as

$$
j_{r}=\frac{C(m, t)}{P} \partial p_{1} / \partial r \mathrm{gm} \cdot \mathrm{cm}^{-2} \cdot \mathrm{sec}^{-1}
$$


where

$$
\begin{aligned}
\mathrm{C}(\mathrm{m}, \mathrm{t})= & \text { constant depending on the gas species and temperature, } \\
& \mathrm{gm} \cdot \mathrm{cm}^{-1} \cdot \mathrm{sec}^{-1} \\
\mathrm{p}_{1}= & \text { partial pressure of the vapor of the thermoelectric material, } \\
& \text { atmospheres. } \\
\mathrm{P}= & \text { total pressure in system, atmospheres }
\end{aligned}
$$

A complete development for the constant, $C(m, t)$, can be found in a previous report ${ }^{(1)}$ by the author on this subject.

Neglecting the slight spatial dependence of $C(m, t)$ in Equation (2) and solving Laplace's equation for $p_{1}$ for the particular geometry of Figure 1 will give the required expression for $j_{r}$. In other words, one must determine a solution to the following equation for appropriate boundary conditions,

$$
\partial^{2} p_{1} / \partial r^{2}+\frac{1}{r} \partial p_{1} / \partial r+\partial^{2} p_{1} / \partial z^{2}=0
$$

where

$$
\begin{aligned}
& r=\text { radial coordinate of Figure } 1 \\
& z=\text { axial coordinate of Figure } 1
\end{aligned}
$$

The expression for $p_{1}$ which satisfies Equation (3) is then used in Equation (2). The boundary conditions best describing the environment of the couple in Figure 1 are:

$$
\begin{aligned}
& \text { (1) } \partial \mathrm{p}_{1} / \partial \mathrm{r}=0 \text { at } \mathrm{r}=\mathrm{r}_{2} \\
& \text { (2) } \partial \mathrm{p}_{1} / \partial \mathrm{z}=0 \text { at } \mathrm{z}=0 \\
& \text { (3) } \quad \mathrm{p}_{1}=0 \quad \text { at } \mathrm{z}=\ell
\end{aligned}
$$

(4) $p_{1}=f(z)$ at $r=r_{1}$ where $f(z)$ is the equilibrium vapor pressure of the thermoelectric material along the surface of the element. 
The solution of Equation (3) for the preceding boundary conditions is

$$
p_{1}=\frac{2}{\ell} \sum_{n=1}^{\infty} \frac{F\left(\lambda_{n} r_{2} ; \lambda_{n} r\right)}{F\left(\lambda_{n} r_{2} ; \lambda_{n} r_{1}\right)} \cos \lambda_{n} z \int_{0}^{l} f(z) \cos \lambda_{n} z d z
$$

where

$$
\begin{aligned}
F(x ; y) & =I_{1}(x) K_{0}(y)+K_{1}(x) I_{0}(y) \\
I_{\nu} & =\text { modified Bessel function of the first kind of order } \nu \\
K_{\nu} & =\text { modified Bessel function of the second kind of order } \nu \\
\ell & =\text { length of annular segment depicted in Figure } 1 \\
\lambda_{n} & =(2 \mathrm{n}-1) \pi / 2 \ell
\end{aligned}
$$

The function, $f(z)$, generally has the form

$$
f(z)=A \exp [-B / T(z)]
$$

where

$A$ and $B$ are constants of the thermoelectric material

$T(z)=$ surface temperature along axial coordinate of the element, " $\mathrm{K}$ Assuming the distribution of temperature along the surface of the thermoelectric element is linear, $\mathrm{T}$ becomes

$$
T=T_{h}-\left(T_{h}-T_{c}\right) z / \ell
$$


where

$$
\begin{aligned}
& \mathrm{T}_{\mathrm{h}}=\text { thermoelectric element hot junction temperature, }{ }^{\circ} \mathrm{K} \\
& \mathrm{T}_{\mathrm{c}}=\text { thermoelectric element cold junction temperature, }{ }^{\circ} \mathrm{K}
\end{aligned}
$$

Substitution of Equation (5) and (6) into Equation (4) completes the solution of $p_{1}$. For this analysis,

$$
\begin{aligned}
& A=\exp (16.23) \\
& B=25.97 \times 10^{3}
\end{aligned}
$$

which are values taken from work by D. Northrup ${ }^{(2)}$. A more complete discussion of the above developments can be found in Reference (1)

Assuming the series expression for $p_{1}$ as given in Equation (4) converges uniformly, the partial derivative, $\partial \mathrm{p}_{1} / \partial \mathrm{r}$, and thus $\mathrm{j}_{\mathrm{r}}$ can be numerically evaluated for values of the dimensionless variables $r / \ell$ and $z / \ell$, with the exception of the point $\left(z=0, r=r_{1}\right)$ which, in this case, is the intersection of two incompatible boundary conditions, (2) and (4). Figure 2 plots $\partial \mathrm{p}_{1} / \partial \mathrm{r}$ at $\mathrm{r}=\mathrm{r}_{1}$ as a function of $\mathrm{z} / \ell$ for a typical set of parameters. For example, the parameters $r_{1} / \ell=0.380$ and $r_{2} / \ell=0.580$ of Figure 2 would be representative of a cylindrical thermoelectric element of $0.380^{\prime \prime}$ diameter and $0.500^{\prime \prime}$ length separated from the surrounding insulation by an annular gap of 0.100 inch.

Using an expression from Reference (1) to evaluate $\mathrm{C}(\mathrm{m}, \mathrm{t})$ of Equation (2) for a mixture of Argon gas and $\mathrm{PbTe}$ vapor at $\mathrm{T}=600^{\circ} \mathrm{C}$ gives

$$
\mathrm{C}(\mathrm{m}, \mathrm{t})=0.0019 \mathrm{gm} \cdot \mathrm{cm}^{-1} \cdot \mathrm{sec}^{-1}
$$

This value of $C(m, t)$ and the values of $\partial p_{1} / \partial r$ from Figure 2 defines $j_{r_{1}}$ (for the above parameters) for various pressures of cover gas. Assume, for the following analysis, that the generated pressure is constant with time. Substituting Equation (2) for $r=r_{1}$ into Equation (1) and integrating will give 


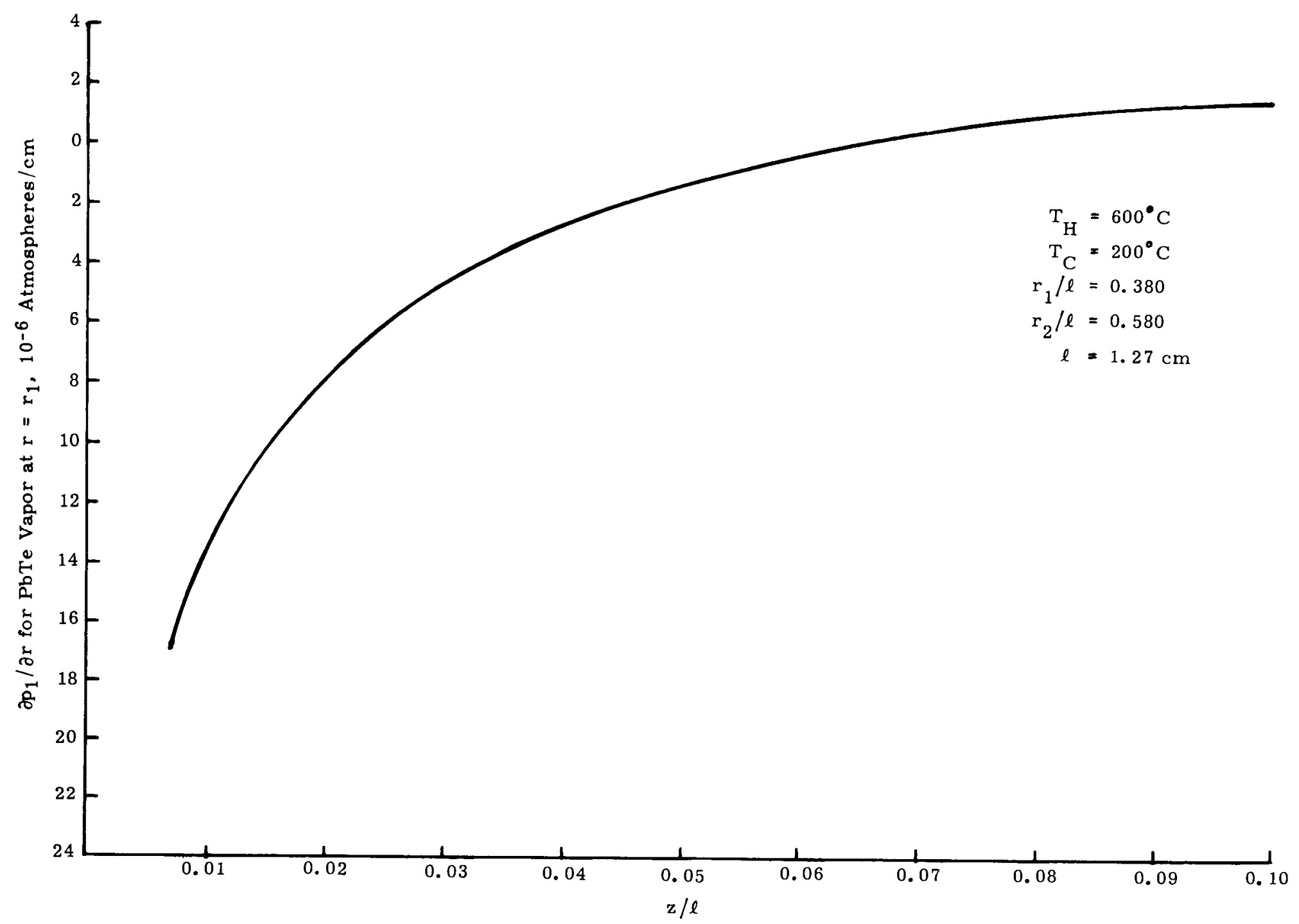

Figure 2. Partial pressure gradient of $\mathrm{PbTe}$ vapor near $\mathrm{z}=0$ 


$$
r=r_{o}-j_{r_{1}} t / p
$$

where

$$
\begin{aligned}
& r_{0}=\text { initial radius of thermoelectric element, } \mathrm{cm} \\
& t=\text { time, sec } \\
& \rho=\text { density of thermoelectric material, } \mathrm{gm} \cdot \mathrm{cm}^{-3}
\end{aligned}
$$

Figure 3 shows the profile, after one year, of a PbTe thermoelectric element as calculated from Equation (7) for one atmosphere generator pressure of Argon and the configuration parameters stated in Figure 2 . Values of $j_{\mathbf{r}_{1}}$ near $z=0$ were determined by evaluating $\partial \mathrm{p}_{1} / \partial \mathrm{r}$ for points in the annular region slightly outside the boundary, $r_{1}$, where the discontinuity at $z=0$ could be avoided. Note the rounding of element near the hot end due to diffusion of material away from the element. The element also shows a region of material deposition immediately below the eroded section. Almost all of the redistribution of material occurs within the first 40 to 50 percent of the element. The profile of Figure 3 is typical of the deterioration resulting from the particular configuration and boundary conditions of Figure 1. Increasing or decreasing the boundary $r_{2}$ of Figure 1 respectively increases and decreases the partial pressure gradients, $\partial \mathrm{p}_{1} / \partial \mathrm{r}$, and thus the severity of erosion; but the shape of the element remains generally the same.

\section{Couple Behavioral Analysis}

Initial speculation on the effect of erosion on generator performance suggested that for constant heat input, the hot junction temperature would rise due to increase in thermal resistance of each element and the power output would decrease due to increases in electrical resistance. This prediction was essentially correct. This was shown by comparing the temperatures and power outputs of whole couples with eroded couples as calculated by a computer design code, VINCE TOM-MOD. 1. 


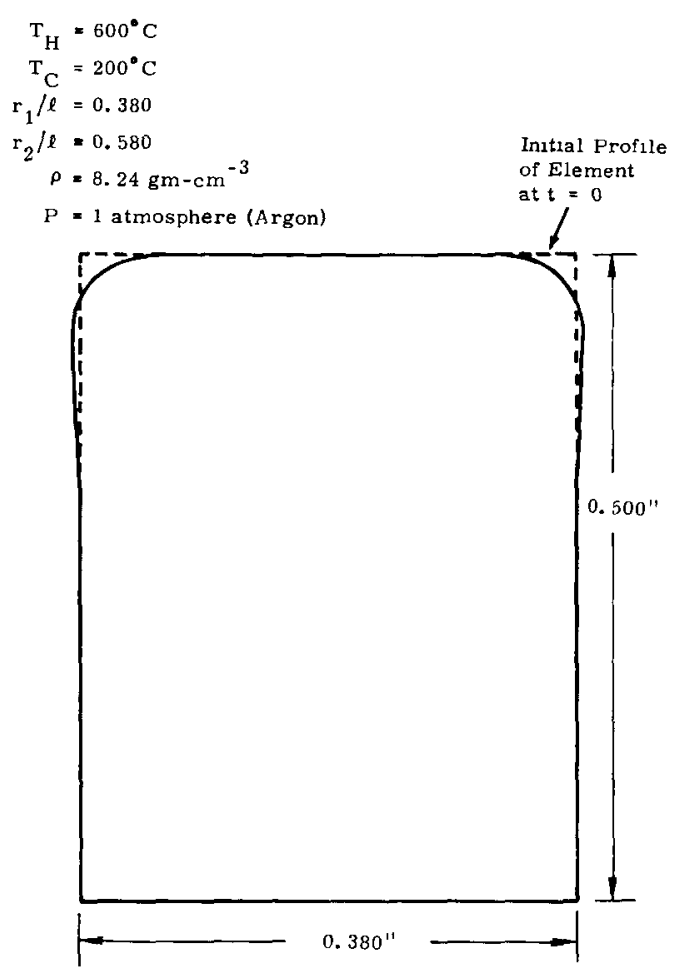

Figure 3. Profile of thermoelectric element showing erosion after one year

This code was originally developed by Martin Marietta, Inc. and is unique, in at least one feature, in allowing variable cross sectional areas for the elements. Using this code, the power outputs and hot junction temperatures of eroded couples were determined for constant heat input and cold junction temperature. Figure 4 shows the plots, for selected intervals of time, of a normalized power output for ten couples, i. e., the ratio of power output of the couples to their initial power; and the hot junction temperature. The power output in early life appears to be dictated by the combination of increasing hot junction temperature and electrical resistance. In later life, the behavior is dominated by the rapid increase in electrical resistance of the couples due to the advanced state of erosion. It is interesting that for the particular parameters stated in Figure 4, this model predicts zero area for the " $P$ " elements at their hot end contacts within approximately 2 years for $P=1$ atmosphere. 


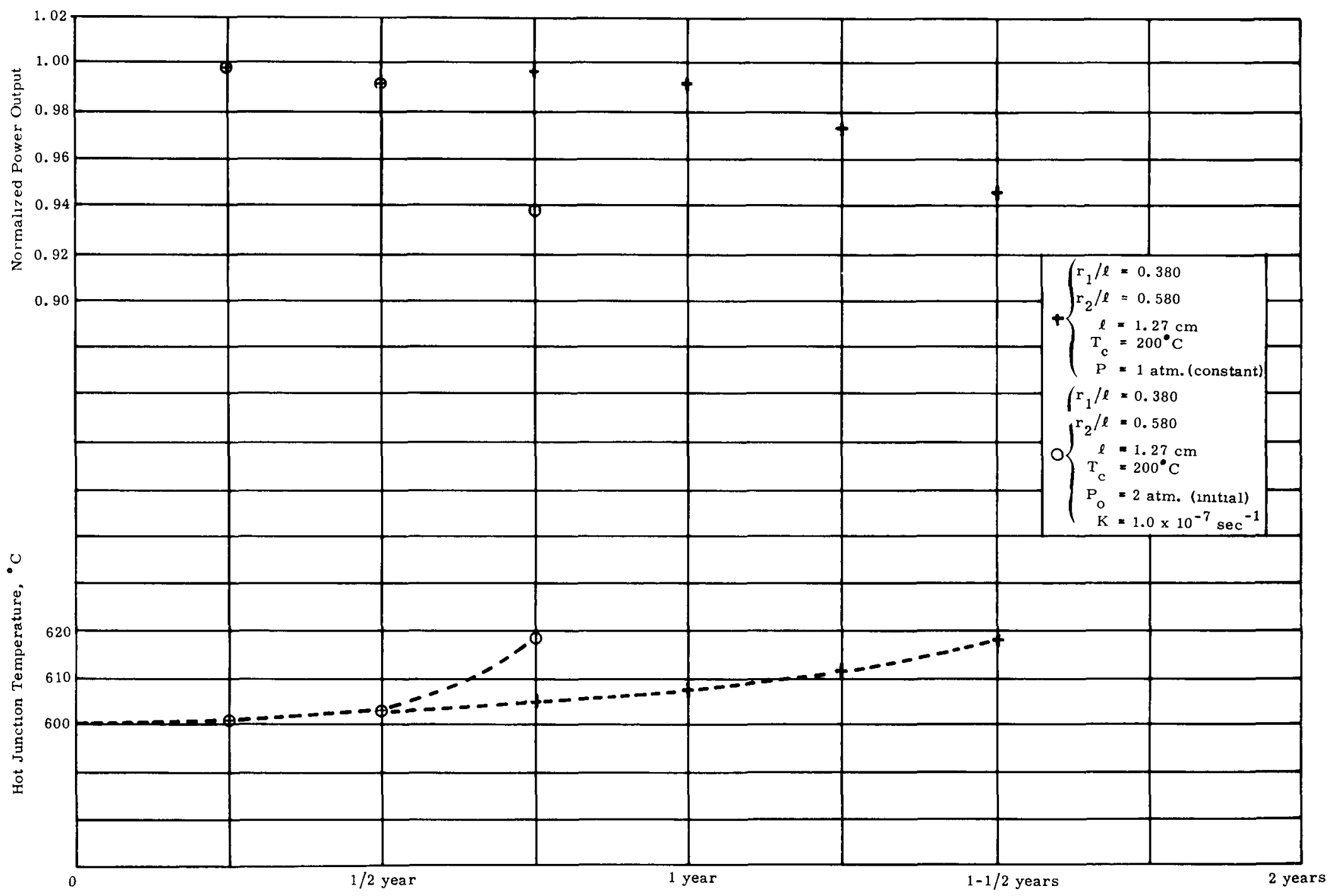

Figure 4. Performance history of thermoelectric couples showing effect of erosion 
In addition to the analysis in which the generator pressure was held constant in time, an analysis was made which allows for pressure decay as a function of time. This condition would be present in most gas filled generators operating in space. For this case, the generator pressure, P, in Equation (2) was assumed to be of the form

$$
P=P_{0} e^{-K t} \text { atmospheres }
$$

where

$$
\begin{aligned}
P_{O} & =\text { initial generator pressure, atmospheres } \\
K & =\text { constant depending on the leak rate and volume of generator, } \sec ^{-1} \\
t & =\text { time, sec }
\end{aligned}
$$

Substitution of Equation (8) into $j_{r_{1}}$ of Equation (1) and integrating results in

$$
r=r_{0}-j_{r_{1}}\left(P_{o}\right)\left(e^{K t}-1\right) / \rho K
$$

where $j_{r_{1}}\left(P_{o}\right)$ is $j_{r_{1}}$ evaluated for the initial pressure, $P_{0}$. This derivation assumes that the slow loss of generator pressure does not perturb the steady state equilibrium of the gas system. Equation (9) can be used in the same fashion as Equation (7) to calculate the radius and hence the cross section area of the thermoelectric elements as a function of time. Figure 4 shows couple performance for this condition as calculated by the aforementioned computer code, VINCE TOM-MOD. 1. Note that for $\mathrm{P}_{\mathrm{O}}=2$ atmospheres of Argon and $\mathrm{K}=1.0 \times 10^{-7} \mathrm{sec}^{-1}$, the resulting deterioration in couple performance occurs earlier for the same configuration parameters, $r_{1} / \ell$ and $r_{2} / \ell$, than in the preceding case. For the present case, the occurrence of zero contact area for the " $P$ " element accurred at about 0.8 year as compared to 2 years for the constant pressure case. 
There are several deficiencies in the model that should be mentioned. The above analyses predicted complete erosion of the " $\mathrm{P}$ " elements at their hot end contacts. For spring loaded couples this is not realistic since the spring loading will keep the shortened element in contact with the hot shoe for a much longer period. However, this condition was not studied, and due to this uncertainty in couple behavior for severe erosion, only the first portion of the performance histories are plotted in Figure 4.

No account was taken of the increase in material loss that will occur due to the increases in hot junction temperature. Since the material flux, $j_{r}$, is highly dependent on temperature, this increase, even for small changes, may be significant.

This model, $\mathrm{p}_{1}$, assumes in the solution for the partial pressure distribution a constant boundary, $r=r_{1}$, with time. This, of course, is not the case. However, the changes in $p_{1}$ and $j_{r_{1}}$ due to boundary changes is not likely to be of such significance as to change the conclusions of this analysis.

\section{Conclusions}

The preceding study, based on the model described, shows that there can be material loss from thermoelectric elements even in generators using a cover gas. This erosion of the elements could cause a significant portion of the degradation observed in current thermoelectric generators. It is, however, not of such magnitude to account for all of the degradation. 


\section{REFERENCES}

1. Kinney, R. D., The Evaporative Erosion of Thermoelectric Elements in Some Thermoelectric Generators, SC-RR-70-534, Sandia Laboratories, Albuquerque, New Mexico, September 1970 (U).

2. Northrop, D. A., Vaporization of Some Commercial Telluride Thermoelements, SC-TM-68-500, Sandia Laboratories, Albuquerque, New Mexico, July 1968. 


\section{DISTRIBUTION:}

TID-4500 (56th Ed.) UC-36 (150)

U. S. Atomic Energy Commission (5) Division of Space Nuclear Systems Space Electric Power Office Washington, D. C. 20545

Attn: G. A. Newby Assistant Director G. P. Dix, Chief Safety Branch R. T. Carpenter, Chief Isotope Power Sys. Branch

J. A. Powers, Chief Isotopes Fuels and Matls. Br. C. E. Johnson, Chief Reactor Power Sys. Branch

U. S. Atomic Energy Commission Space Nuclear Propulsion Office Washington, D. C. 40545

Attn: R. S. Decker, Jr., Chief Safety Branch

U. S. Atomic Energy Commission Division of Isotope Development Washington, D. C. 20545

U. S. Atomic Energy Commission Director of Regulation

Washington, D. C. 20545

Attn: C. K. Beck Deputy Director R. W. Klecker Div. of Reactor Licensing

U. S. Atomic Energy Commission Division of Biology and Medicine Washington, D. C. 20545

Attn: J. Z. Holland

Fallout Studies Branch H. D. Bruner, Asst. Dir. Medical and Health Research

U. S. Atomic Energy Commission Space Nuclear Propulsion Office Albuquerque Extension Albuquerque Operations Office P. O. Box 5400

Albuquerque, New Mexico 87115 Attn: H. P. Smith
U. S. Atomic Energy Commission

Albuquerque Operations Office

P. O. Box 5400

Albuquerque, New Mexico 87115

Attn: B. W. Colston, Director Space and Special Projects Division For: J. Nicks J. F. Burke, Director Operational Safety Div.

AEC Site Representative National Aeronautics and Space Adm. Manned Spacecraft Center Houston, Texas 77058

Attn: W. C. Rémini Bldg. 16, Code ZS-5

Deputy I. G. for Insp. \& Safety USAF

Directorate of Nuclear Safety

Nuclear Power Division Kirtland Air Force Base New Mexico 87117

Jet Propulsion Laboratory California Institute of Technology 4800 Oak Grove Drive Pasadena, California 91103

Attn: A. L. Klascius Radiation Health and Safety

Los Alamos Scientific Laboratory (5) P. O. Box 1663

Los Alamos, New Mexico 87544

Attn: Dr. L. D. P. King

Dr. Wright Langham

C. F. Metz, CMB-1

F. W. Schonfeld, CMF-5

J. A. Leary, CMB-11

Monsanto Research Corporation

Mound Laboratory

P. O. Box 32

Miamisburg, Ohio 45342

Attn: G. R. Grove

Thomas B. Kerr

Code RNS

National Aeronautics and Space Adm.

Washington, D. C. 20545 
DISTRIBUTION: (cont)

Mr. Glenn Goodwin

National Aeronautics and Space Adm. Ames Research Center

$\mathrm{N}-200-4$

Moffett Field, California 94035

D. B. Shuster, 1200

J. R. Holland, 5321

C. F. Bild, 7500

G. A. Fowler, 9000

J. R. Banister, 9150

R. C. Maydew, 9320

National Aeronautics and Space Adm.

L. A. Hopkins, Jr., 9500

Goddard Space Flight Center

Glenn Dale Road

Greenbelt, Maryland 20771

Attn: A. W. Fihelly Nimbus Project

Naval Facilities Engineering Com. Dept. of the Navy, Code 042

Washington, D. C. 20390

A. J. Clark, Jr., 9510

S. L. Jeffers, 9512

ARPIC, 9512 (2)

S. McAlees, Jr., 9513

G. J. Hildebrandt, 9520

G. J. Hildebrandt, 9521 (Actg)

J. Jacobs, 9522

Central Files, 3422-1

L. C. Baldwin, 3412

L. L. Alpaugh, 3412

Space Nuclear Propulsion Office

G. C. McDonald, 3416

Lewis Research Center

21000 Brookpark Road

Cleveland, Ohio 44135

Attn: L. Nichols

Mr. George Mandel

Information Specialist

Aerospace Safety Research and

Data Institute

NASA Lewis Research Center

21000 Brookpark Road

Cleveland, Ohio 44135

Union Carbide Corporation (2)

Nuclear Division

P. O. Box X

Oak Ridge, Tennessee 37831

Attn: R. A. Robinson

Isotope Development Center

B. R. Fish

Health Physics Division

U. S. Public Health Service

Nat. Ctr. for Radiological Health

1901 Chapman Avenue

Rockville, Maryland 20852

Attn: Nuclear Facilities Section 